\title{
ASSESSMENT OF CYTO/GENOTOXICITY OF IRINOTECAN IN V79 CELLS USING THE COMET, MICRONUCLEUS, AND CHROMOSOME ABERRATION ASSAY
}

\author{
Vilena KAŠUBA ${ }^{1}$, Ružica ROZGAJ ${ }^{1}$, Marija GAMULIN², and Ivančica TROŠIĆ ${ }^{1}$ \\ Institute for Medical Research and Occupational Health ${ }^{l}$, Clinical Hospital Centre Zagreb, \\ Oncology Clinic ${ }^{2}$, Zagreb, Croatia \\ Received in April 2009 \\ Accepted in December 2009
}

\begin{abstract}
Irinotecan is a topoisomerase I interactive agent, widely used in the treatment of metastatic colorectal cancer. The genotoxic effects of the maximum single dose $\left(18 \mu \mathrm{g} \mathrm{mL}^{-1}\right)$, recommended monotherapy dose $\left(9 \mu \mathrm{g} \mathrm{mL}^{-1}\right)$, and recommended combined therapy dose $(4.5 \mu \mathrm{g} \mathrm{mL}-1)$ of irinotecan were studied on V79 cells using the comet assay, chromosome aberration assay, and micronucleus test. The cells were treated with irinotecan for $2 \mathrm{~h}$ or $24 \mathrm{~h}$. The statistical significance of the results was determined using the one-way ANOVA test and a nonparametric Mann Whitney $U$ test. The comet assay did not show dose-dependent or time-dependent effects. The chromosome aberration analysis showed large DNA rearrangements, i.e., chromosome exchanges. Although the exposed cultures showed a significant increase in micronucleated cells in respect to control, no dose-dependent relation was established among the treated cultures. Timedependent effect was also not observed.
\end{abstract}

KEY WORDS: alkaline comet assay, antineoplastic drug, cell cultures, DNA and cytogenetic damage, topoisomerase

Irinotecan is a semi-synthetic derivative of camptothecin, a quinoline-based alkaloid and DNA topoisomerase I inhibitor $(1,2)$. It inhibits DNA cleavage and re-ligation induced by topoisomerase I $(3,4)$. Normally, it is prescribed only for colorectal cancer cases that have not responded to standard chemotherapy with 5-fluorouracil.

As an approved anticancer agent, irinotecan damages the DNA molecule indirectly, by inhibiting enzymes which modulate DNA topology. Irinotecan stops the growth of cancer cells by preventing the development of elements necessary for cell division, i.e. it keeps the chromosomes wound tight, so the cell cannot make proteins, and as a result, cells stop growing (5).

Topoisomerases are enzymes that produce reversible single-strand breaks in the DNA during replication. These enzymes wind and unwind the DNA that makes up chromosomes. Irinotecan binds to the topoisomerase I DNA complex and prevents religation of the DNA strand, which leads to double-strand DNA breakage and cell death (6).

Irinotecan is S-phase cell cycle specific $(1,7,8)$. $\mathrm{Li}$ and co-workers (9) found that cells in the S-phase were 100 to 1,000 times more sensitive to camptothecin in vitro than cells in $\mathrm{G}_{1}$ or $\mathrm{G}_{2}$. Irinotecan proved clastogenic in the mammalian in vitro (chromosome aberrations in Chinese hamster ovary cells) and in vivo (micronucleus test in mice) test systems (10).

Here we studied the genotoxic effects of the maximum single dose of $18 \mu \mathrm{g} \mathrm{mL}^{-1}$, recommended monotherapy dose of $9 \mu \mathrm{g} \mathrm{mL}^{-1}$, and recommended combined therapy dose of $4.5 \mu \mathrm{g} \mathrm{mL}^{-1}$ of irinotecan on cultured V79 cells using the alkaline comet assay, 
cytochalasin B blocked micronucleus assay, and the chromosome aberration assay.

We investigated whether this drug was genotoxic to the cells in the applied doses, and how time of exposure influenced the results.

\section{MATERIAL AND METHODS}

\section{Reagents}

Irinotecan $\left(\mathrm{Campto}^{\circledR}\right)$ was purchased from Aventis Pharma Ltd. It was used in the form of irinotecan hydrochloride trihydrate as a $5 \mathrm{~mL}$ sterile solution for infusion (at the concentration of $20 \mathrm{mg} \mathrm{mL}^{-1}$ ). A stock solution for the study was prepared with sterile redistilled water. The final concentrations used in our in vitro experiment were: $18 \mu \mathrm{g} \mathrm{mL}^{-1}, 9 \mu \mathrm{g}$ $\mathrm{mL}^{-1}$, and $4.5 \mu \mathrm{g} \mathrm{mL}^{-1}$, corresponding to respective maximal single dose of $700 \mathrm{mg} \mathrm{m}^{-2}$, recommended monotherapy dose of $350 \mathrm{mg} \mathrm{m}^{-2}$, and recommended combined therapy dose of $180 \mathrm{mg} \mathrm{m}^{-2}$. Mitomycin C (MMC) was purchased from Sigma (St. Louis, MO, USA).

\section{Cell culture}

Chinese hamster V79 cell line was cultured as a monolayer in an F-10 medium (Sigma) supplemented with $20 \%$ calf serum, penicillin $\left(100 \mathrm{IU} \mathrm{mL}^{-1}\right)$, and streptomycin $\left(100 \mu \mathrm{g} \mathrm{mL}^{-1}\right)$. Cells, whose passage number was below 20, were maintained at $37^{\circ} \mathrm{C}$ in a humidified atmosphere containing $5 \%$ $\mathrm{CO}_{2}$. For the experiment, the cells were seeded at $1.5 \times 10^{4}$ cells $\mathrm{mL}^{-1}$ to $2.0 \times 10^{4}$ cells mL $\mathrm{mL}^{-1}$. After a $24-\mathrm{h}$ growth, the culture was treated with irinotecan for $2 \mathrm{~h}$ and $24 \mathrm{~h}$, and then washed twice with cold phosphate buffered saline (PBS), followed by incubation for an additional $24 \mathrm{~h}$ in a fresh medium. Its genotoxic effect was studied for three doses: $4.5 \mu \mathrm{g} \mathrm{mL}^{-1}, 9 \mu \mathrm{g} \mathrm{mL}^{-1}$, and $18 \mu \mathrm{g} \mathrm{mL}^{-1}$. MMC $\left(0.5 \mu \mathrm{g} \mathrm{mL}^{-1}\right)$ was used as positive control. Untreated control was also included in the experiment.

\section{Alkaline comet assay}

The alkaline version of the comet assay was performed according to the method of Singh et al. (11) with minor modifications. Fully frosted microscope slides (Surghipath, Richmond, IL, USA) were precoated with $1 \%$ of normal melting point agarose (NMP) (Sigma). After solidification, this layer was removed. $300 \mu \mathrm{L}$ of $0.6 \% \mathrm{NMA}$ was pipetted onto the slides, covered with a cover slip, and placed on a metal tray over ice for $10 \mathrm{~min}$ to solidify. Cell suspensions of V79 hamster cells were mixed with $100 \mu \mathrm{L}$ of $0.5 \%$ low melting point (LMP) agarose (Sigma), pipetted over the $0.6 \%$ NMP agarose, and placed on ice for 10 minutes to solidify. $0.5 \%$ LMP was used as the final protective layer. Slides were placed overnight in a cold lysis solution containing $2.5 \mathrm{~mol} \mathrm{~L}^{-1} \mathrm{NaCl}$, $100 \mathrm{mmol} \mathrm{L}^{-1} \mathrm{Na}_{2}$ EDTA, $10 \mathrm{mmol} \mathrm{L}^{-1}$ Tris, pH 10, and $1 \%$ sodium $\mathrm{N}$-lauroylsarcosinate to which $10 \%$ of dimethylsulphoxide (DMSO) and $1 \%$ Triton X100 have been added just before use. After the lysis, the slides were placed in an electrophoresis buffer (300 $\mathrm{mmol} \mathrm{L}^{-1} \mathrm{NaOH}$ and $1 \mathrm{mmol} \mathrm{L}^{-1} \mathrm{Na}_{2}$ EDTA, pH13) for 20 min to allow for unwinding of the DNA. Electrophoresis was conducted in the same buffer by applying an electric current of $300 \mathrm{~mA}$, at $25 \mathrm{~V}$ for 20 min using a horizontal electrophoresis power tank (Life Technologies, Gaithersburg, MD, USA). Finally, the slides were washed three times for five minutes with a neutralisation buffer $\left(0.4 \mathrm{~mol} \mathrm{~L}^{-1}\right.$ Tris, $\left.\mathrm{pH} 7.5\right)$ and stained with ethidium bromide ( $20 \mu \mathrm{g} \mathrm{mL}^{-1}$, Sigma). All steps of the comet assay preceding electrophoresis were performed on ice to prevent DNA repair and effects of metabolic processes. Furthermore, to avoid position effects during electrophoresis, two parallel replicate slides per sample were prepared, and each replicate was processed in a different electrophoretic run.

Image analysis was performed using an automatic digital analysis system (Comet Assay II, Perceptive Instruments Ltd., Suffolk, Halstead, UK) fitted with Leitz Orthoplan fluorescence microscope equipped with an excitation filter of $515 \mathrm{~nm}$ to $560 \mathrm{~nm}$.

Nuclei were excited with green light, and the emitted red spectrum was captured by a $25 \mathrm{x}$ immersion objective. Images of 100 randomly selected nuclei were analysed per sample. Experiments were carried out in triplicate. The tail length, the length of migration starting from the leading edge of the head, and the tail moment were selected as sensitive indicators of genotoxicity.

\section{Cytochalasin B-blocked micronucleus test}

Duplicate cultures were seeded in a Lab-Tek II Chamber Slide W/Cover (Nagle Nunc International, Naperville, IL, USA) and maintained in an incubator at $+37^{\circ} \mathrm{C}$ in humified atmosphere containing $5 \% \mathrm{CO}_{2}$ for $24 \mathrm{~h}$ before treatment.

In the 2-h treatment, the medium was removed, cells washed twice with PBS, fresh medium with cytochalasin B (Sigma) (in $0.6 \mu \mathrm{g} \mathrm{mL}^{-1}$ final 
concentration) was added, and cultivation continued for another $24 \mathrm{~h}$.

In the 24-h treatment, irinotecan and cytochalasin B (Sigma) (in $0.6 \mu \mathrm{g} \mathrm{mL}^{-1}$ final concentration) were added $24 \mathrm{~h}$ after seeding, and cultivation was continued for another $24 \mathrm{~h}$.

At the end of the incubation period, the medium was removed, cells washed twice with PBS, trypsinised, resolved in complete medium and centrifuged, swollen in $0.075 \mathrm{~mol} \mathrm{~L}^{-1} \mathrm{KCl}$, fixed in methanol:acetic acid (5:1), spread on slides, air-dried, and stained with $5 \%$ Giemsa stain (Merck, Darmstadt, Germany). Two thousand binucleated cells with well preserved cytoplasm were analysed for each irinotecan dose (1000 binucleated cells for each parallel culture).

\section{Chromosome aberration assay}

Triplicate cultures were seeded in Lab-Tek II Chamber Slide W/Cover (Nagle Nunc International, Naperville, IL, USA) as described above. After a 24$\mathrm{h}$ growth, the cultures were treated with irinotecan and incubated for $2 \mathrm{~h}$ and $24 \mathrm{~h}$. In the 2-h treatment, the medium was removed; cells washed twice with PBS, and incubated with a fresh F-10 medium for another $22 \mathrm{~h}$. In the 24-h treatment, the drug was left in the cultures until harvesting. Colchicine (Sigma) was added two hours before harvesting to arrest cells in metaphase. At the end of the incubation period, the medium was removed; cells washed twice with PBS, trypsinised, resolved in complete medium and centrifuged, swollen in $0.075 \mathrm{~mol} \mathrm{~L}^{-1} \mathrm{KCl}$, fixed in methanol: acetic acid $(3: 1)$, spread on slides, airdried, and stained with $5 \%$ Giemsa stain. Six hundred metaphases per irinotecan dose (200 metaphases per parallel culture) were analysed.

\section{Statistical analysis}

For the comet assay and micronucleus test, data were analysed using one-way analysis of variance (ANOVA) for multiple comparisons. Tukey post hoc test was used to examine the differences between samples. A probability level of $\mathrm{P}<0.05$ was considered to be significant. The nonparametric Mann-Whitney $\mathrm{U}$ test was performed to analyse chromosome aberrations.

\section{RESULTS}

\section{The alkaline comet assay}

The lengths and shapes of the comets reflect the amount of DNA fragmentation. Table 1 shows the results of the alkaline comet assay for 2-h and 24-h exposure to irinotecan. The ANOVA test did not show significant differences between the exposed and control samples either in the tail length or tail moment. However the tail length differed significantly between positive and negative control $(\mathrm{P}=0.0479)$ for the 2-h exposure.

After 24-h exposure, there was a significant difference in the tail length and tail moment between samples treated with $9 \mu \mathrm{g} \mathrm{mL}^{-1}$ of irinotecan and either control. Positive control samples significantly differed in both parameters from samples treated with $18 \mu \mathrm{g} \mathrm{mL}^{-1}$, and $4.5 \mu \mathrm{g} \mathrm{mL}^{-1}$ of irinotecan, while from samples treated with $9 \mu \mathrm{g} \mathrm{mL}^{-1}$ of irinotecan they significantly differed only in the tail moment. The difference was also significant in the tail length and tail moment between all three irinotecan-treated groups.

\section{Micronucleus assay}

The results of the micronucleus (MN) frequency test are presented in Table 2. After $2 \mathrm{~h}$ of exposure to irinotecan, all irinotecan-treated samples had a significantly higher micronucleus frequency than negative or positive control samples. Samples treated with $4.5 \mu \mathrm{g} \mathrm{mL}^{-1}$ had a significantly lower MN frequency than samples treated with $18 \mu \mathrm{g} \mathrm{mL}^{-1}$ or $9 \mu \mathrm{g} \mathrm{mL}^{-1}$ of irinotecan. These differences were not dose-dependent.

After the 24-h exposure, positive control samples and $9 \mu \mathrm{g} \mathrm{mL}^{-1}$ of irinotecan showed a significant increase compared to the negative control. Significant difference was observed between positive control and $4.5 \mu \mathrm{g} \mathrm{mL}^{-1}$ of irinotecan. The sample treated with $18 \mu \mathrm{g} \mathrm{mL}^{-1}$ of irinotecan could not be analysed due to low number of surviving cells.

\section{Chromosome aberration analysis}

Table 3 shows the results of the chromosome aberration analysis. In 2-h treatment, dicentric chromosomes increased with the dose of irinotecan, but the increase was not statistically significant. The nonparametric Mann-Whitney U test showed significant differences in acentric fragments between irinotecan doses of $18 \mu \mathrm{g} \mathrm{mL}^{-1}$ and $4.5 \mu \mathrm{g} \mathrm{mL}^{-1}(\mathrm{P}<$ $0.05)$. We also observed significant differences in tetraploidy between the sample treated with $4.5 \mu \mathrm{g}$ $\mathrm{mL}^{-1}$ of irinotecan and positive control $(\mathrm{P}<0.05)$, and between samples treated with $4.5 \mu \mathrm{g} \mathrm{mL}^{-1}$ and $9 \mu \mathrm{g} \mathrm{mL}^{-1}$ of irinotecan $(\mathrm{P}<0.05)$. 
Table 1 The effects of 2-h and 24-h irinotecan treatment on V79 cells obtained with the comet assay after $2 h$ and $24 h$

\begin{tabular}{|c|c|c|c|c|}
\hline \multirow{2}{*}{ Treatment } & \multicolumn{2}{|c|}{ Effects after 2-h treatment } & \multicolumn{2}{|c|}{ Effects after 24-h treatment } \\
\hline & Tail length / $\mu \mathrm{m}$ & Tail moment & Tail length / $\mu \mathrm{m}$ & Tail moment \\
\hline \multicolumn{5}{|c|}{ Irinotecan $18 \mu \mathrm{g} \mathrm{mL}^{-1}$} \\
\hline Mean \pm SE & $25.74 \pm 1.03$ & $1.40 \pm 0.14$ & $25.72 \pm 0.68^{b}$ & $1.38 \pm 0.13^{\mathrm{b}, \mathrm{d}}$ \\
\hline Median & 21.79 & 0.87 & 23.08 & 0.77 \\
\hline Range & 13.46 to 124.36 & 0.01 to 16.95 & 12.82 to 50.00 & 0.01 to 10.15 \\
\hline \multicolumn{5}{|c|}{ Irinotecan $9 \mu \mathrm{g} \mathrm{mL} \mathrm{m}^{-1}$} \\
\hline Mean \pm SE & $19.41 \pm 0.75$ & $0.88 \pm 0.29$ & $47.56 \pm 2.17^{\mathrm{a}}$ & $4.96 \pm 0.45^{\mathrm{a}, \mathrm{b}}$ \\
\hline Median & 17.95 & 0.26 & 44.87 & 3.87 \\
\hline Range & 12.18 to 146.79 & 0.01 to 57.58 & 13.46 to 110.25 & 0.12 to 23.61 \\
\hline \multicolumn{5}{|c|}{ Irinotecan $4.5 \mu \mathrm{g} \mathrm{mL}^{-1}$} \\
\hline Mean \pm SE & $20.28 \pm 0.63$ & $0.58 \pm 0.05$ & $24.28 \pm 0.32^{\mathrm{b}, \mathrm{d}}$ & $0.82 \pm 0.10^{\mathrm{b}, \mathrm{d}}$ \\
\hline Median & 19.23 & 0.29 & 22.11 & 0.42 \\
\hline Range & 13.46 to 109.61 & 0.01 to 4.97 & 12.18 to 73.72 & 0.01 to 4.96 \\
\hline \multicolumn{5}{|c|}{ Positive control } \\
\hline \multicolumn{5}{|c|}{$\mathrm{MMC} 0.5 \mu \mathrm{g} \mathrm{mL}^{-1}$} \\
\hline Mean \pm SE & $30.71 \pm 0.87^{\mathrm{a}}$ & $1.84 \pm 0.13$ & $48.78 \pm 2.01^{\mathrm{a}}$ & $3.33 \pm 0.25^{\mathrm{a}}$ \\
\hline Median & 26.92 & 1.23 & 40.38 & 2.27 \\
\hline Range & 15.38 to 89.74 & 0.02 to 9.25 & 15.38 to 153.84 & 0.003 to 26.53 \\
\hline \multicolumn{5}{|c|}{ Negative control* } \\
\hline Mean \pm SE & $18.16 \pm 0.44$ & $0.56 \pm 0.11$ & $18.16 \pm 0.44$ & $0.56 \pm 0.11$ \\
\hline Median & 16.67 & 0.17 & 16.67 & 0.17 \\
\hline Range & 10.26 to 57.05 & 0.01 to 5.46 & 10.26 to 57.05 & 0.01 to 5.46 \\
\hline
\end{tabular}

The results are presented as mean \pm SE (standard error). The experiment was carried out in duplicate. One hundred cells were analysed per sample.

Superscript letters denote statistical differences between the groups $(P<0.05)$ :

${ }^{a}$-significantly different from non-treated control sample;

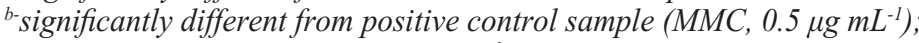

c-significantly different from $4.5 \mu \mathrm{g} \mathrm{mL^{-1 }}$ sample

${ }^{d}$ significantly different from $9 \mu \mathrm{g} \mathrm{mL}^{-1}$ sample

* non-treated cells

After the 24-h treatment, only the effects of the lowest concentration of irinotecan $\left(4.5 \mu \mathrm{g} \mathrm{mL}^{-1}\right)$ could be analysed. The number of surviving cells in other sample groups was not sufficient for statistical analysis (Table 3 ).

\section{DISCUSSION}

In this study we evaluated the cytotoxic and genotoxic effects of three therapeutically relevant doses of irinotecan $\left(\mathrm{Campto}^{\circledR}\right)$ on V79 cells, following $2 \mathrm{~h}$ and $24 \mathrm{~h}$ of exposure in vitro. The choice of a prolonged exposure was based on previous reports on the mechanism of cytotoxicity of camptothecin analogues (12).

To get a better insight into the nature of intracellular damage caused by the treatment, we used the alkaline comet assay, cytochalasin B blocked micronucleus assay, and chromosome aberration analysis.
These endpoints showed that irinotecan simultaneously induced primary DNA damage, structural chromosome aberrations, and mitotic spindle damage in treated cells.

The alkaline comet assay did not show statistically significant differences either in the tail length or tail moment between samples treated with irinotecan for two hours. The 24-hour exposure did however yield significant differences, which were not dose- or timedependent. Curiously enough, we found more DNA damage with irinotecan dose of $9 \mu \mathrm{g} \mathrm{mL}^{-1}$ than with $18 \mu \mathrm{g} \mathrm{mL}^{-1}$. This may be because highly fragmented DNA from cells treated with the latter dose is not captured on microgel. Camptothecin causes singlestrand breaks in DNA, but the breaks are rapidly repaired after drug removal, while the cytotoxic action of camptothecin is sustained (13). Kopjar et. al. (14), tested the toxicity of $4.6 \mu \mathrm{g} \mathrm{mL}^{-1}$ and $9 \mu \mathrm{g} \mathrm{mL}^{-1}$ irinotecan on human blood cells, and also reported higher cytotoxicity at a lower dose of the drug. 
Table 2 The effects of 2-h and 24-h irinotecan treatment on V79 cells obtained with the micronucleus assay

\begin{tabular}{|c|c|c|}
\hline Treatment & $\begin{array}{c}\text { Frequency of micronuclei in V79 cells } \\
\text { after 2-h treatment }\end{array}$ & $\begin{array}{c}\text { Frequency of micronuclei in V79 cells } \\
\text { after } 24 \text {-h treatment }\end{array}$ \\
\hline \multicolumn{3}{|l|}{ Irinotecan $18 \mu \mathrm{g} \mathrm{mL}^{-1}$} \\
\hline $\mathrm{Mean} \pm \mathrm{SE}$ & $75.5 \pm 0.5^{\mathrm{a}, \mathrm{b}, \mathrm{c}}$ & No binuclear cells \\
\hline No. of cells with MN & 71 & \\
\hline \multicolumn{3}{|l|}{ Irinotecan $9 \mu \mathrm{g} \mathrm{mL}^{-1}$} \\
\hline Mean \pm SE & $85.0 \pm 2.0 \mathrm{a}, \mathrm{b}, \mathrm{c}$ & $61.5 \pm 11.5^{\mathrm{a}}$ \\
\hline No. of cells with MN & 68 & 54 \\
\hline \multicolumn{3}{|l|}{ Irinotecan $4.5 \mu \mathrm{g} \mathrm{mL}^{-1}$} \\
\hline Mean \pm SE & $17.5 \pm 1.5^{\mathrm{a}, \mathrm{b}}$ & $28.0 \pm 3.0^{\mathrm{b}}$ \\
\hline No. of cells with MN & 14.5 & 31 \\
\hline \multicolumn{3}{|l|}{ Positive control } \\
\hline \multicolumn{3}{|l|}{ MMC $0.5 \mu \mathrm{g} \mathrm{mL}^{-1}$} \\
\hline Mean \pm SE & $34.0 \pm 4.0^{\mathrm{a}}$ & $72.5 \pm 6.5^{\text {a }}$ \\
\hline No. of cells with MN & 31 & 65.5 \\
\hline \multicolumn{3}{|l|}{ Negative control* } \\
\hline Mean \pm SE & $4.5 \pm 0.5$ & $4.5 \pm 0.5$ \\
\hline No. of cells with MN & 4.5 & 4.5 \\
\hline
\end{tabular}

The results are presented as mean $\pm S E$ (standard error). The experiment was carried out in duplicate. One thousand cells per sample were analysed.

Superscript letters denote statistical differences between the groups $(P<0.05)$ :

${ }^{a}$-significantly different from non-treated control sample;

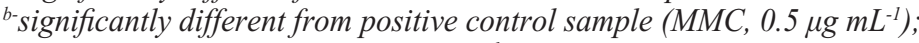

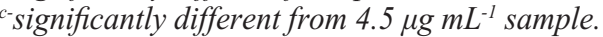

* Non-treated cells

Table 3 Chromosome aberration analysis of V79 cells treated with irinotecan in vitro

\begin{tabular}{lccccccccccc}
\hline Treatment & Gap & Sb & Db & AF & Dic & PC & CE & Ring & TPL & ER & PULV \\
\hline Irinotecan $18 \mu \mathrm{g} \mathrm{mL}^{-1}$ & 1 & 1 & 3 & $11^{*}$ & 4 & 0 & 3 & 1 & 14 & 0 & 4 \\
Irinotecan $9 \mu \mathrm{g} \mathrm{mL}^{-1}$ & 1 & 8 & 2 & 6 & 1 & 0 & 0 & 1 & $5^{*}$ & 1 & 1 \\
Irinotecan $4.5 \mu \mathrm{gL} \mathrm{m}^{-1}$ & 1 & 1 & 1 & 2 & 1 & 0 & 0 & 0 & 15 & 0 & 3 \\
Positive control & 6 & 5 & 27 & 47 & 4 & 0 & 32 & 2 & $4^{*}$ & 6 & 8 \\
MMC $0.5 \mu \mathrm{gL}^{-1}$ & & & & & & & & & & &
\end{tabular}

\section{4-h treatment}

Irinotecan $18 \mu \mathrm{g} \mathrm{mL}^{-1} \quad$ Insufficient number of metaphases

Irinotecan $9 \mu \mathrm{g} \mathrm{mL}^{-1} \quad$ Insufficient number of metaphases

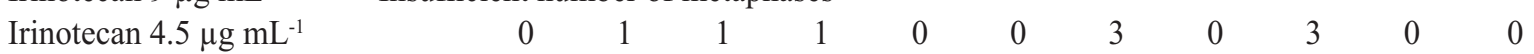

Positive control

MMC $0.5 \mu \mathrm{g} \mathrm{mL}{ }^{-1}$

Insufficient number of metaphases

Negative control non-treated cells

$\begin{array}{lllllllllll}1 & 4 & 0 & 0 & 0 & 0 & 0 & 0 & 2 & 0 & 1\end{array}$

Note: to evaluate the frequency of chromosome aberrations, 600 cells per sample were analysed.

$S b$ - chromatid break, Db-chromosomal break, $A F$ - acentric fragment, Dic - dicentric chromosome, $P C$ - polycentric chromosome, $C E$ - tri- and tetra-radial chromatid exchange, TPL - tetraploidy, ER - endoreduplication, PULV - pulverisation

"- significant difference with respect to irinotecan $4.5 \mu \mathrm{g} \mathrm{mL} L^{-1}$ sample, by nonparametric Mann-Whitney U test

The other possible explanation for our results could be the apoptotic elimination of cells whose DNA was not repaired.

Recent studies have shown that camptothecin and its analogues can strongly induce apoptosis in different types of cells $(13,15,16)$. Literature shows that irinotecan-induced changes in gene expression profiles in vitro and in vivo are consistent with the temporary delay in $\mathrm{G}_{1}-\mathrm{S}$ transition and with enhanced responsiveness to apoptosis, both of which may 
contribute to the synergistic interactions between this drug and antimetabolites (17). In a study by Ohyama et al. (18), irinotecan induced apoptosis of SW-620 cells by increasing the poly(ADP-ribose) polymerase (PARP) cleavage (to $60 \%$ vs. $7 \%$ basal level). Gibson et al. $(19,20)$ reported increased apoptosis in the intestines of breast cancer-bearing dark agouti rats after treatment with irinotecan. Daza et al. (21) described DNA strand breaks in $\mathrm{G}_{0}$ human leukocytes after one-hour exposure to irinotecan, that were repaired $24 \mathrm{~h}$ after exposure.

Godard et al. (22) found that the comet assay was able to detect stabilised cleavable complexes and apoptosis induced by camptothecin. DNA strand breaks were present after one hour of treatment, and disappeared within $24 \mathrm{~h}$ after drug removal from Chinese hamster ovary $(\mathrm{CHO})$ cells, DC3F cells, and DC3F/C-10 cells. Kinetics studies allowed to discriminate between these early DNA damages and DNA fragmentation related to apoptosis characterised by the reappearance of DNA strand breaks $48 \mathrm{~h}$ after treatment (22). Other studies on animal and human cell lines confirm the ability of camptothecin to cause high primary DNA damage, mainly in the form of singleand double-strand breaks. Gradzka et al. (23) suggest that a higher initial rate of repair of replication-related double-strand breaks may contribute to the relative camptothecin resistance of murine lymphoma cells.

Ollikainen et al. (24) found a slight increase in DNA single-strand breaks in human mesothelioma cells (M14K and M25K) induced by SN-38 (an active metabolite of irinotecan) at a concentration of $10^{-8} \mathrm{mmol} \mathrm{L}^{-1}$.

Chromosome damage caused by exposure to irinotecan has also been described. Anderson and Berger (25) showed that irinotecan induced sister chromatid exchanges, chromosomal aberrations, and mutations in specific mammalian genes. Voight et al. (26) observed chromatid breaks associated with radial chromosome configurations and sister chromatid exchanges after $24 \mathrm{~h}$ of exposure to irinotecan. However, near maximum clastogenic effects were evident immediately after a 2 -h drug exposure.

In our study, we analysed for chromosome aberrations only those samples that were exposed to irinotecan for two hours because prolonged exposure would completely block cell proliferation and no metaphases would be obtained. Treatment with irinotecan significantly affected the frequency of acentric fragments. Although a four-fold increase was found for dicentric chromosomes at the dose of
$18 \mu \mathrm{g} \mathrm{mL}^{-1}$ of irinotecan compared to other applied doses, the result was not significant. In addition, we found a significant increase in the frequency of tetraploidy in the treated samples.

All these results are consistent with previous reports, which indicate that cell sensitivity to camptothecin is the highest during their progression through the $\mathrm{S}$ phase, and that the drug delays the cell cycle traverse in the $S / G_{2}$ phase $(27,28)$.

The ability of camptothecin to induce $\mathrm{MN}$ was confirmed both on transgenic (29) and nontransgenic mice $(30,31)$. In their in vivo clastogenicity study, Hardman et al. (32) reported that irinotecan significantly elevated MN frequency in mouse peripheral blood erythrocytes. Aydemir and Bilaloglu (33) found an increase in MN frequency in the bone marrow cells of mice treated with topotecan (an analogue of irinotecan). Kopjar et al. (14) found a significant increase in the MN frequency in human lymphocytes even at a lower dose of $4.6 \mu \mathrm{g} \mathrm{mL}^{-1}$ of irinotecan.

The best explanation of the nature of damage caused by irinotecan was provided by Attia et al. (34). By combining the micronucleus test with fluorescence in situ hybridisation (FISH) using a mouse minor satellite DNA probe they distinguished $\mathrm{MN}$ of clastogenic and aneugenic origin and found that irinotecan was genotoxic and produced chromosomal damage that ended up as MN.

\section{CONCLUSIONS}

Our findings indicate that therapeutic doses of irinotecan are genotoxic to V79 cells, but the effect is neither dose- nor time-dependent under the experimental conditions. A two-hour exposure to irinotecan did not cause DNA single-strand breaks in V79 cells at applied concentrations, while a twentyfour-hour exposure resulted in DNA single-strand breaks regardless of the concentration. Chromosome aberration analysis confirmed the clastogenic effects of the drug and showed its potential to block cell division after $24 \mathrm{~h}$ of exposure. This study has singled out the micronucleus assay as the most reliable method for sensitive detection of cellular damage caused by irinotecan. Although no dose- or time-dependent effect was observed, this test provided the most consistent results, since both treatments resulted in increased MN frequency compared to control samples. 
Regardless of the limitations of in vitro studies, their results could help to predict the outcome of therapies with antineoplastic drugs. Based on previous reports and our own results, we can conclude that the further studies are needed to shed more light on the mechanisms of genotoxic action of irinotecan at the cell level.

\section{Acknowledgements}

This study was supported by the Croatian Ministry of Science, Education and Sports as a part of the grant no.0220222148-2137 and 022-0222411-2406.

\section{REFERENCES}

1. Hsiang YH, Hertzberg R, Hecht S, Liu LF. Camptothecin induces protein-linked DNA breaks via mammalian DNA topoisomerase I. J Biol Chem 1985;260:14873-8.

2. Hsiang YH, Liu LF. Identification of mammalian DNA topoisomerase I as an intracellular target of the anticancer drug camptothecin. Cancer Res 1988;48:1722-6.

3. Hertzberg RP, Caranfa MJ, Hecht SM. On the mechanism of topoisomerase I inhibition by camptothecin: evidence for binding to an enzyme-DNA complex. Biochemistry 1989;28:4629-38.

4. Kjeldsen E, Svejstrup JQ, Gromova H, Alsner J, Westergaard O. Camptothecin inhibits both the cleavage and religation reactions of eucaryotic DNA topoisomerase I. J Mol Biol 1992;228:1025-30.

5. Bailly C. Homocamptothecins: potent topoisomerase I inhibitors and promising anticancer drugs. Crit Rev Oncol Hematol 2003;45:91-108.

6. Eng WK, Faucette L, Johnson RK, Sternglanz R. Evidence that DNA topoisomerase I is necessary for the cytotoxic effects of camptothecin. Mol Pharmacol 1988;34:755-60.

7. Slichenmyer WJ, Rowinsky EK, Donehower RC, Kaufmann $\mathrm{SH}$. The current status of camptothecin analogues as antitumor agents. J Natl Cancer Inst 1993;85:271-91.

8. Rothenberg ML, Kuhn JG, Schaf LJ, Drengler RL, Eckhardt SG, Villalonacalero MA, Hammond L, Miller LL, Petit RG, Rowinsky EK, Vonhoff DD. Alternative dosing scheduels for Irinotecan. Oncology (Huntington) 1998;12(Suppl 6):6871.

9. Li LH, Fraser TJ, Olin EJ, Bhuyan BK. Action of camptothecin on mammalian cells in culture. Cancer Res 1972;32:2643-50.

10. Irinotecan. USP DI. Vol. 1, Drug information for the health care professional. 20 $0^{\text {th }}$ ed. Englewood (CO): Micromedex Inc.; 2000.

11. Singh N, McCoy M, Tice R, Schneider E. A simple technique for quantification of low levels of DNA damage in individual cells. Exp Cell Res 1988;175:184-91.

12. Houghton PJ, Stewart CF, Thompson J, Santana VM, Furman WL, Friedman HS. Preclinical and clinical results with Irinotecan - extending principles learned in model system to clinical trails design. Oncology (Williston Park). 1998;12(8 Suppl 6):84-93.
13. Yoshida A, Ueda T, Wano Y, Nakamura T. DNA damage and cell killing by camptothecin and its derivative in human leukemia HL-60 cells. Jpn J Cancer Res 1993;84:566-73.

14. Kopjar N, Želježić D, Lucić Vrdoljak A, Radić B, Ramić S, Milić M, Gamulin M, Pavlica V, Fučić A. Irinotecan toxicity to human blood cells in vitro: relationship between various biomarkers. Basic Clin Pharmacol Toxicol 2007;100:40313.

15. Sánchez-Alcázar JA, Bradbury DA, Brea-Calvo G, Navas P, Knox AJ. Camptothecin-induced apoptosis in non-small cell lung cancer is independent on cyclooxygenase expression. Apoptosis 2003;8:639-47.

16. Ciesielski MJ, Fenstermaker RA. Synergistic cytotoxicity, apoptosis and protein linked DNA breakage by etoposide and camptothecin in human U87 glioma cells: dependence on tyrosine phosphorilation. J Neurooncol 1999;41:223-34.

17. Minderman H, Conroy JM, O Loughlin KL, McQuaid D, Quinn P, Li S, Pendyala L, Nowak NJ, Baer MR. In vitro and in vivo irinotecan-induced changes in expression profiles of cell cycle and apoptosis-associated genes in acute myeloid leukemia cells. Mol Cancer Therap 2005;4:885-900.

18. Guichard S, Arnould S, Hennebelle I, Bugat R, Canal P. Combination of oxaliplatin and irinotecan on human colon cancer cell lines: activity in vitro and in vivo. Anti-Cancer Drugs 2001;12:741-51.

19. Gibson RJ, Bowen JM, Inglis MR, Cummins AG, Keefe DM. Irinotecan causes severe small intestinal damage, as well as colonic damage, in the rat with implanted breast cancer. J Gastroentrol Hepatol 2003;18:1095-100.

20. Gibson RJ, Keefe DMK, Thompson FM, Clarke JM, Goland GJ, Cummins AG. Effect of interleukin-11 on ameliorating intestinal damage after methotrexate treatment of breast cancer in rats. Dig Dis Sci 2002;47:2751-7.

21. Daza P, Torreblanca J, Garcia-Herdugo G, Moreno FJ. DNA strand-breaks induced by the topoisomerase I inhibitor camptothecin in unstimulated human white blood cells. Cell Biol Int 2002;26:707-13.

22. Godard T, Deslandes E, Sichel F, Poul JM, Gauduchon P. Detection of topoisomerase inhibitor-induced DNA strand breaks and apoptosis by the alkaline comet assay. Mutat Res 2002;520:47-56.

23. Gradzka I, Skierski J, Szumiel I. DNA repair, cell cycle progression and cell death following Camptothecin treatment in two murine lymphoma L5178Y sublines. Cell Biochem Funct 1998;16:239-52.

24. Ollikainen T, Knuuttila A, Suhonen S, Taavitsainen M, Jekunen A, Mattson K, Linnainmaa K. In vitro sensitivity of normal human mesothelial and malignant mesothelioma cell lines to four new chemotherapeutic agents. Anticancer Drugs 2000;11:93-9.

25. Anderson RD, Berger NA. Mutagenicity and carcinogenicity of topoisomerase-interactive agents. Mutat Res 1994;309:10942.

26. Voight W, Matsui S, Yin MB, Burhans WC, Minderman H, Rustum YM. Topoisomerase- I inhibitor SN-38 can induce DNA damage and chromosomal aberrations independent from DNA synthesis. Anticancer Res 1998;18(5A):3499505.

27. Del Bino G, Lassota P, Darzynkiewicz Z. The S-phase cytotoxicity of camptothecin. Exp Cell Res 1991;193:2735. 
28. Tsao YP, D'Arpa P, Liu LF. The involvement of active DNA synthesis in camptothecin-induced $\mathrm{G}_{2}$ arrest: altered regulation of p34cdc2/cyclin B. Cancer Res 1992;52:18239.

29. Mahabir AG, Benthem Jv, Korsten H, Lynch AM, Bailey L, de Vries A, Hendriksen CF, van Steeg H. Detecting genotoxic effects of potential clastogens: An in vivo study using the transgenic lacZ plasmid and the MutaTM Mouse model. Mutat Res 2008;652:151-7.

30. Holmström M, Winters V. Micronuclei induction by camptothecin and amsacrine in bone marrow of male and female CD-1 mice. Mutagenesis 1992;7:189-93.

31. Bacher LC, Allen JW, Harrington-Brock K, Campbell JA, Moore MM. Genotoxicity of inhibitors of DNA topoisomerase I (camptothecin) and II (m-ASA) in vivo and in vitro. Mutagenesis 1990;5:541-7.

32. Hardman WE, Moyer MP, Cameron IL. Consumption of an omege-3 fatty acids product, INCELL AAFA ${ }^{\mathrm{TM}}$, reduced side-effects of CPT-11 (irinotecan) in mice. Br J Cancer 2002;86:983-8.

33. Aydemir N, Bilaloglu R. Genotoxicity of two anticancer drugs; gentamicine and topotecan, in mouse bone marrow in vivo. Mutat Res 2003;537:43-51.

34. Attia SM, Aleisa AM, Bakheet SA, Al-Yahya AA, Al-Reyaie SS, Ashour AE, Al-Shabanah OA. Molecular cytogenetic evaluation of the mechanism of micronuclei formation induced by camptothecin, topotecan and irinotecan. Environ Mol Mutegen 2009;50:145-51. 


\section{Sažetak \\ PROCJENA CITO-/GENOTOKSIČNOSTI IRINOTEKANA U V79-STANICAMA PRIMJENOM KOMET-TESTA, MIKRONUKLEUS-TESTA I TESTA KROMOSOMSKIH ABERACIJA}

Irinotekan je citotoksični lijek koji inhibira enzim DNA-topoizomerazu I. U širokoj je primjeni u terapiji metastatskog karcinoma kolona i rektuma. U uvjetima in vitro primjenom komet-testa, analize kromosomskih aberacija i mikronukleus-testa na V79-stanicama istražili smo genotoksični učinak maksimalne pojedinačne doze $\left(18 \mu \mathrm{g} \mathrm{mL}^{-1}\right)$, preporučene monoterapijske doze $\left(9 \mu \mathrm{g} \mathrm{mL}^{-1}\right)$ i preporučene doze irinotekana za kombiniranu terapiju $\left(4,5 \mu \mathrm{g} \mathrm{mL}^{-1}\right)$. Kulture stanica bile su tretirane irinotekanom $2 \mathrm{~h}$ i $24 \mathrm{~h}$. Statistička značajnost određivana je jednosmjernim ANOVA-testom i neparametrijskim Mann Whitneyevim U-testom. Komet-testom nije utvrđen učinak koncentracije i/ili vremena izloženosti. Analiza kromosomskih aberacija pokazala je prisutnost izmjena kromatida, tj. porast broja triradijusa i tetraradijusa. Iako je u kulturama stanica izloženim irinotekanu opažen značajan porast broja mikronukleusa u odnosu na kontrolu, nije uočena ovisnost o dozi lijeka ni o vremenu izloženosti u opisanim eksperimentalnim uvjetima. Dobiveni rezultati upućuju na genotoksičnost irinotekana za V79-stanice. Nijednom od primijenjenih metoda nije utvrđena ovisnost učinka irinotekana o vremenu ili dozi.

KLJUČNE RIJEČI: antineoplastični lijekovi, citogenetska oštećenja, oštećenje DNA, stanične kulture, topoizomeraze

CORRESPONDING AUTHOR:

Vilena Kašuba, $\mathrm{PhD}$

Mutagenesis Unit

Institute for Medical Research and Occupational Health

Ksaverska c. 2, HR-10001 Zagreb, Croatia

E-mail:vkasuba@imi.hr 